\title{
Perception of Oral and Dental Health Awareness and Assessment of Dental Habits in Preclinical Dentistry Students: A Questionnaire Study
}

\author{
Aliye Tuğçe GÜRCAN 國, Meltem MERT EREN ${ }^{1}{ }^{2}$, Gülcan ÇAKIR ${ }^{3}$
}

\begin{abstract}
Aim: The oral and dental hygiene behaviors of patients are affected by their dentists. Although dental students attend preclinical courses in their first and second years of education, they are expected to be knowledgeable about oral and dental health due to their future position as being role models for patients. In this study, it was aimed to evaluate the oral and dental health awareness and oral health habits of preclinical dental students.

Material and Methods: 127 preclinical dental students were included in this study. A questionnaire consisting of 39 questions about oral-dental health habits and knowledge levels was prepared. The results were analyzed with the SPSS 22.0 software. A p-value of smaller than 0.05 was considered statistically significant. Chi-squared and Mann-Whitney $\mathrm{U}$ tests were used for statistical analysis.

Results: Frequency of daily tooth brushing, gingival bleeding, halitosis, toothpaste preference, satisfaction with tooth color and frequency of dental visits were found to be statistically significant. There was no significant difference between the 1st-year and 2nd-year student groups in terms of their responses to the questions ( $p>0.05$ ). A statistically significant difference was found between the male and female groups for their responses to the questions on topics such as toothpaste preference, satisfaction with the color of their teeth, frequency of dental examination, frequency of tooth cleaning and toothbrushing time $(\mathrm{p}<0.05)$. It was also found that the oral and dental awareness and dissatisfaction with teeth levels were higher in the female participants.

Conclusion: It was observed that the 1st-year and 2nd-year participants had similar views regarding oral hygiene and attitudes since they had just started their vocational training. Awareness and knowledge levels are expected to increase with class year and as clinical courses progress.
\end{abstract}

Keywords: Oral health awareness; dental habits; preclinical classes; dental faculty students.

\section{Klinik Öncesi Diş Hekimliği Öğrencilerinde Ă̆ız ve Diş Sağlığı Algısı, Farkındalığı ve Dental Alışkanlıkların Değerlendirilmesi: Anket Çalışması}

$\ddot{\mathbf{O Z Z}}$

Amaç: Hastaların ağız ve diş sağlığı davranışları, diș hekimleri tarafından etkilenebilmektedir. Diș hekimliği öğrencilerinin, birinci ve ikinci yıllarında klinik öncesi dersleri almalarına rağmen, hastalara rol model olmaları nedeniyle ağız ve diş sağlığı konusunda bilgi sahibi olmaları beklenmektedir. Bu çalışmada, preklinik düzeyindeki diş hekimliği öğrencilerinin ağız diş sağlığı farkındalıklarının ve ağız sağlığı alışkanlıklarının değerlendirilmesi amaçlanmıştır.

Gereç ve Yöntemler: Çalışmaya 127 preklinik diş hekimliği öğrencisi dahil edildi. Ağız-diş hijyen alışkanlıkları ve bilgi düzeyi ile ilgili 39 sorudan oluşan anket oluşturuldu. Sonuçlar SPSS 22.0 versiyonu ile analiz edildi. Anlamlılık düzeyi 0,05 olarak alındı. İstatistiksel analiz için ki-kare ve Mann-Whitney-U testi kullanıldı.

Bulgular: Günlük diş fırçalama sıklığı, dişeti kanaması, ağız kokusu, diş macunu tercihi, diş renginden memnuniyet ve dental muayene sıklığı ile ilgili sorulara verilen yanıtlar istatistiksel olarak anlamlı bulundu. Sorular açısından sınıf grupları arasında anlamlı farklılık yoktu $(\mathrm{p}>0,05)$. Cinsiyet için; diş macunu tercihi, diş renginden memnuniyet, dental muayene sıklığı, diş temizleme sıklığı, diş fırçalama süreleri gibi sorularda kadın ve erkek grupları arasında istatistiksel olarak anlamlı farklılık bulunmuştur $(\mathrm{p}<0,05)$. Ayrıca ağız ve diş sağlı̆̆ farkındalığının ve dişlerden memnuniyetsizliğin kadınlarda daha yaygın olduğu görülmüştür.

\footnotetext{
1 Altınbaş University Faculty of Dentistry, Department of Pediatric Dentistry, Istanbul, Turkey

2 Altınbaş University Faculty of Dentistry, Department of Restorative Dentistry, Istanbul, Turkey

3 Pediatric Dentist, Sarıyer/Istanbul, Turkey
}

Corresponding Author: Aliye Tuğçe GÜRCAN, e-mail: tugcetanyeri@gmail.com

Received: 16.02.2021. Accented: 07.11.2021 
Sonuç: $\mathrm{Bu}$ çalışmada 1. ve 2. sınıf diş hekimliği öğrencileri arasında cevaplar açısından bir fark bulunmamıştır. Meslek eğitimine yeni başladıkları için ağız hijyenine ve tutumlarına göre benzer bir görüşe sahip oldukları görülmüştür. Öğrencilerin sınıf seviyeleri arttıkça ve klinik dersler başladıkça, farkındalık ve bilgi seviyelerinin artması beklenmektedir.

Anahtar Kelimeler: Ağı sağlığı bilinci; dental alışkanlıklar; preklinik sınıflar; diş hekimliği öğrencileri.

\section{INTRODUCTION}

Dental caries and periodontal diseases, that are among the most common chronic diseases, may be affected with other systemic diseases or increase the risk of progression. In order to provide a good oral health, it is necessary to use interdental aids such as dental floss and other oral care tools, as well as a toothbrush and toothpaste. It is very important to have the ideal and appropriate oral care, as well as sufficient and appropriate information about the individual's oral health and care. Oral health awareness is gained in the family with the implementation of these procedures and education. The level of the knowledge of the family at this point has great importance for both children and adults $(1,2)$.

Patients' oral and dental hygiene behaviors are influenced by their dentists. Their current treatment plan is decided upon by considering their dentist's opinion and according to their existing oral and dental healthcare awareness levels $(3,4)$. As the field of dentistry develops scientifically, dentists have to update their knowledge in this area.

There are several methods in dentistry for prevention of tooth decay that emphasize the patient's responsibility to manage the disease by maintaining oral hygiene, practices of dentistry professionals for disease management and community-based measurements. Preventive methods may be used alone or in combination. The attitudes of dental students may affect their educational responses and the preventive services they will provide (5). Dental students are required to learn and use these procedures related to oral and dental healthcare during their undergraduate education $(6,7,8)$.

Dentists may improve society's knowledge and attitudes about oral and dental health (9). Dental students can be taken as a role model by the community, also supporting and improving society's oral and dental health awareness. It is important for dentistry students to be aware of oral health at the beginning of their education in terms of guiding the patients they will treat in the future (10). Beside these, it is also important to know that oral health affects general health and provide sufficient awareness about oral health for dental students. There have been recent studies conducted to evaluate this awareness in Turkey, as well as in the world in general $(1,11)$.

The aim of this study was to compare the oral health awareness levels and oral health habits in preclinical dental students.

\section{MATERIAL AND METHODS}

A survey model as its research design was used for this study. The field survey model was used to collect data from the participants. A questionnaire, which was used to collect the written opinions of the participants, was used for the data collection process. Ethics committee approval
(Dated 03/01/2018) was obtained from the Ethics Committee for Clinical Research (Number: B.30.2.AYD.0.00.00-480.2/232) of a local university in agreement with the principles of the Declaration of Helsinki. The study complied with the relevant research and publication ethics.

First-year and 2nd-year dental students (preclinical students) were included in this study.

The students were asked to fill in and complete a questionnaire containing questions about their oral and dental habits, self-assessment, awareness and knowledge about their dental health (Table 3). Participation in this study was on a voluntary basis. Participant consent was obtained from volunteer students.

The questionnaire was prepared using a range of validated scales and an extensive literature review of previous studies $(12,13,14,15)$. The relationships between the frequency of daily tooth brushing and selected variables (gingival bleeding, halitosis, tooth color satisfaction, preference of toothpaste and dental visit intervals) were investigated (Table 1). Moreover, the relationships between the duration of daily tooth brushing and selected variables (gingival bleeding, halitosis, tooth color satisfaction, preference of toothpaste and dental visit intervals) were investigated (Table 2). Questions on the relevant topics can be seen in Table 1 and 2.

Table 1. Relationship analysis of the frequency of daily tooth brushing and selected variables

\begin{tabular}{|l|c|c|}
\hline Variables & $\begin{array}{c}\text { Chi-square } \\
\text { statistic }\end{array}$ & p \\
\hline $\begin{array}{l}\text { Have you ever noticed } \\
\text { bleeding in your gums? }\end{array}$ & 16.748 & $\mathbf{0 . 0 2 5 *}$ \\
\hline $\begin{array}{l}\text { Have you ever noticed } \\
\text { bad breath? }\end{array}$ & 11.736 & $\mathbf{0 . 0 0 3 *}$ \\
\hline $\begin{array}{l}\text { What kind of toothpaste } \\
\text { do you use? (multiple } \\
\text { answers possible) }\end{array}$ & 13.889 & $\mathbf{0 . 0 0 0 *}$ \\
\hline $\begin{array}{l}\text { How pleased are you } \\
\text { with the color of your } \\
\text { teeth? }\end{array}$ & 14.725 & $\mathbf{0 . 0 0 0 *}$ \\
\hline $\begin{array}{l}\text { Do you seek a routine } \\
\text { dental visit for oral } \\
\text { hygiene maintenance? }\end{array}$ & 17.284 & $\mathbf{0 . 0 0 1 *}$ \\
\hline p $<0.05$ & \\
\hline
\end{tabular}

Table 2. Relationship analysis of the duration of daily tooth brushing and selected variables

\begin{tabular}{|l|c|c|}
\hline Variables & $\begin{array}{c}\text { Chi-square } \\
\text { statistic }\end{array}$ & p \\
\hline $\begin{array}{l}\text { Have you ever noticed } \\
\text { bleeding in your gums? }\end{array}$ & 22.670 & $0.001^{*}$ \\
\hline $\begin{array}{l}\text { Have you ever noticed bad } \\
\text { breath? }\end{array}$ & 21.233 & $0.002^{*}$ \\
\hline $\begin{array}{l}\text { What kind of toothpaste do } \\
\text { you use? }\end{array}$ & 27.199 & $0.000^{*}$ \\
\hline $\begin{array}{l}\text { How pleased are you with } \\
\text { the color of your teeth }\end{array}$ & 38.997 & $0.003^{*}$ \\
\hline $\begin{array}{l}\text { Do you seek a routine } \\
\text { dental visit for oral } \\
\text { hygiene maintenance }\end{array}$ & 25.553 & $0.005^{*}$ \\
\hline
\end{tabular}


Table 3. Survey reliability test results

\begin{tabular}{|l|l|l|l|l|}
\hline $\begin{array}{l}\text { Reliability } \\
\text { Tests }\end{array}$ & $\begin{array}{l}\text { Cronbach } \\
\text { Alpha }\end{array}$ & Split & Parallel & Strict \\
\hline $\begin{array}{l}\text { Reliability } \\
\text { Results }\end{array}$ & 0.902 & $\begin{array}{l}0.892- \\
0.901\end{array}$ & 0.899 & 0.897 \\
\hline
\end{tabular}

\section{Statistical Analyses}

In this study, SPSS 22.0 Programme was used for analyzing the data. The significance level was taken as 0.05. Chi-squared and Mann-Whitney U tests were used for the statistical analyses. The responses were evaluated in the terms of gender and class level.

The responses to the questionnaire were analyzed using Kolmogorov-Smirnov and Shapiro-Wilk normality tests. The H1 hypothesis which was not rejected indicated that the normal distribution of the factors was not achieved. Therefore, non-parametric statistical methods were used in this study.

\section{RESULTS}

The Cronbach's Alpha, Split-Half Reliability, Parallel and Strict Parallel model methods were used to test the reliability of the questionnaire, in present study (Table 3). Over $70 \%$ of these criteria is an indication that the survey was successful and appliable. It reveals that the internal consistency of the questionnaire is provided and the inferences can be trusted. As can be seen in Table 3, the percentage values specified and desired in all four tests passed the confidence criterion. It has been obtained that the results of the sample are consistent with high reliability values.

The initial total number of the participants was 138 , but individuals who did not provide consent and those who filled the questionnaire incompletely were excluded from the study. As a result, 127 participants were included, and the response rate was $92 \%$.

Seventy-nine of the students were in their 1st year of education, while 48 of them were in their 2 nd year. There were 75 female and 52 male participants. Additionally, 96 of the participants were Turkish students, and 31 were foreign students. The participants had an age range of 1827, and their mean age was $19.48 \pm 1.42$ (Table 4).

Table 4. Descriptive statistics

\begin{tabular}{|l|l|c|c|}
\hline Variable & Group & Frequency (n) & Percent (\%) \\
\hline Gender & Male & 52 & 40.9 \\
\hline \multirow{2}{*}{ Nationality } & Female & 75 & 59.1 \\
\hline \multirow{5}{*}{ Class } & Other & 96 & 75.6 \\
\hline \multirow{5}{*}{ Age } & $\mathbf{1 s t}$ & 31 & 24.40 \\
\hline \multirow{5}{*}{} & $\mathbf{2 n d}$ & 79 & 62.2 \\
\cline { 2 - 5 } & $\mathbf{1 8}$ & 48 & 37.8 \\
\cline { 2 - 5 } & $\mathbf{1 9}$ & 22 & 17.3 \\
\cline { 2 - 5 } & $\mathbf{2 0}$ & 61 & 48.0 \\
\cline { 2 - 5 } & $\mathbf{2 1}$ & 29 & 22.8 \\
\cline { 2 - 5 } & $\mathbf{2 2}$ & 4 & 3.1 \\
\cline { 2 - 5 } & $\mathbf{2 3}$ & 5 & 3.9 \\
\cline { 2 - 5 } & $\mathbf{2 4}$ & 3 & 2.9 \\
\cline { 2 - 5 } & $\mathbf{2 5}$ & 1 & 0.8 \\
\cline { 2 - 5 } & $\mathbf{2 7}$ & & 0.8 \\
\hline
\end{tabular}

The responses of the participants to the questions on oral health habits, awareness, self-assessment and knowledge are shown in Table 5.

As a primary result of the study, the participants' frequency of daily toothbrushing, gingival bleeding, halitosis, toothpaste preference, satisfaction with tooth color and dental visit intervals were found statistically significant (Table 1) (respectively $\mathrm{p}=0.025, \mathrm{p}=0.003$, $\mathrm{p}=0.00, \mathrm{p}=0.00, \mathrm{p}=0.01)$. The frequencies and rates compared for each variable are also given in Table 5.

The tooth brushing frequency of the students was found as 2 times a day. In the group of the participants who brushed their teeth twice a day or more frequently, there were no gingival bleeding and halitosis, and these individuals were careful in choosing toothpaste. They were also satisfied with their teeth on a higher level than the other groups, and they visited a dentist twice a year. There were no significant differences between the groups in terms of their responses to the questions shown in Tables 6-1, 6-2, 6-3. The responses to the questions shown in Tables 7-1, 7-2, 7-3 were found significantly different between the male and female groups ( $p<0.05)$. The percentage of students who define their dental health as good was $72.4 \%$. For the question of satisfaction of their tooth color, the score with the highest frequency was found as 8 in the 1st-year participants by $24.1 \%$ and as 7 in the 2nd-year participants by $29.2 \%$. Furthermore, it was determined that the oral and dental health awareness levels and levels of dissatisfaction with teeth were more common in the female group.

On the other hand, there was no significant difference in the participants' responses to the question about noticing gingival bleeding and halitosis ( $p>0.05)$ (Table 7-1).

The rate of the participants who attended dental examination twice a year was $32.3 \%$, and the rate of those who attended once was $25.2 \%$. The rate of those who attended only when there was a problem was the highest compared to the others $(42.5 \%)$. The percentage of those who did not know about interdental aids was higher than those who knew about them (respectively $61.4 \%$ and $38.6 \%$ ) (Table 5). These are the second set of the results of this study. 
Table 5. Students' answers to the questions

\begin{tabular}{|c|c|c|c|}
\hline Questions & Response & $\mathbf{n}$ & $\%$ \\
\hline \multirow[t]{3}{*}{ How often do you clean your teeth? } & Once a day & 14 & 11.0 \\
\hline & Twice a day & 98 & 77.2 \\
\hline & $>$ Twice & 5 & 11.8 \\
\hline \multirow[t]{2}{*}{ How often do you change your brush? } & 3 months & 83 & 65.4 \\
\hline & 6 months & 44 & 34.6 \\
\hline \multirow{2}{*}{ Do you use dental floss? } & Yes & 47 & 37.0 \\
\hline & No & 80 & 63.0 \\
\hline \multirow[t]{2}{*}{ Do you smoke? } & Yes & 26 & 20.5 \\
\hline & No & 101 & 79.5 \\
\hline \multirow{4}{*}{ How long do you clean your teeth each time? } & 1 minute & 22 & 17.3 \\
\hline & $\leq 2$ minutes & 61 & 48.0 \\
\hline & $>2$ minutes & 43 & 33.9 \\
\hline & Don’t know & 1 & 0.8 \\
\hline \multirow[t]{5}{*}{ What kind of toothpaste do you use? } & Sensitive & 47 & 37.0 \\
\hline & Normal & 43 & 33.9 \\
\hline & Whitening & 33 & 26.0 \\
\hline & Fluoride-free & 4 & 3.1 \\
\hline & No toothpaste & 0 & 0 \\
\hline \multirow{2}{*}{$\begin{array}{l}\text { Do you use supplementary toothpaste? } \\
\text { (for example Tooth Mousse, } \\
\text { remineralisation agents) }\end{array}$} & Yes & 26 & 20.5 \\
\hline & No & 101 & 79.5 \\
\hline \multirow{3}{*}{$\begin{array}{l}\text { How much time does it take cleaning } \\
\text { your teeth? }\end{array}$} & $1-2$ minutes & 57 & 44.9 \\
\hline & $3-5$ minutes & 62 & 48.8 \\
\hline & $>5$ minutes & 8 & 6.3 \\
\hline \multirow{4}{*}{$\begin{array}{l}\text { How often have you visited a dentist/dental clinic in the past } \\
12 \text { months? }\end{array}$} & Once & 31 & 24.4 \\
\hline & Twice & 41 & 32.3 \\
\hline & More than twice & 34 & 26.8 \\
\hline & None & 21 & 16.5 \\
\hline \multirow{3}{*}{$\begin{array}{l}\text { Do you seek a routine dental visit for oral hygiene } \\
\text { maintenance? }\end{array}$} & Once in a year & 32 & 25.2 \\
\hline & Twice in a year & 41 & 32.3 \\
\hline & Only if a problem occurs & 54 & 42.5 \\
\hline \multirow{10}{*}{$\begin{array}{l}\text { How pleased are you with the color of your teeth? Num. scale } \\
1-10\end{array}$} & 1 & 5 & 3.9 \\
\hline & 2 & 2 & 1.6 \\
\hline & 3 & 4 & 3.1 \\
\hline & 4 & 9 & 4.1 \\
\hline & 5 & 17 & 5.4 \\
\hline & 6 & 21 & 6.5 \\
\hline & 7 & 26 & 10.5 \\
\hline & 8 & 27 & 22.3 \\
\hline & 9 & 6 & 24.7 \\
\hline & 10 & 10 & 17.9 \\
\hline \multirow[t]{2}{*}{ Have you ever noticed bleeding in your gums? } & Yes & 72 & 56.7 \\
\hline & No & 55 & 43.3 \\
\hline \multirow[t]{2}{*}{ Do you know what interdental aids are? } & Yes & 49 & 38.6 \\
\hline & No & 78 & 61.4 \\
\hline \multirow{2}{*}{$\begin{array}{l}\text { Do you educate people about oral } \\
\text { hygiene procedures? }\end{array}$} & Yes & 67 & 52.8 \\
\hline & No & 60 & 47.2 \\
\hline \multirow[t]{2}{*}{ Do you know about the Xylitol? } & Yes & 18 & 14.2 \\
\hline & No & 109 & 85.8 \\
\hline \multirow[t]{2}{*}{ Do you know about the Fluoride? } & Yes & 96 & 75.6 \\
\hline & No & 31 & 24.4 \\
\hline The use of fluoride-toothpaste begins & 2 & 11 & 8.7 \\
\hline & 3 & 9 & 7.1 \\
\hline & 6 & 43 & 33.9 \\
\hline & 10 & 39 & 30.7 \\
\hline & Don’t know & 125 & 19.6 \\
\hline How would you describe your present state of dental health? & Excellent & 16 & 12.6 \\
\hline & Good & 92 & 72.4 \\
\hline & Moderate & 18 & 14.2 \\
\hline & Don't know & 1 & 0.8 \\
\hline Have you ever noticedbad breath? & Yes & 60 & 47.2 \\
\hline & No & 67 & 52.8 \\
\hline
\end{tabular}


Table 6-1. Mann-Whitney U test results based on class levels

\begin{tabular}{|c|c|c|c|c|c|}
\hline Question & Class & Answers & $\mathbf{n}$ & $\%$ & $\mathrm{p}$ \\
\hline \multirow{4}{*}{$\begin{array}{l}\text { Have you ever noticed } \\
\text { bleeding in your gums? }\end{array}$} & \multirow[t]{2}{*}{1} & Yes & 44 & 55.7 & \multirow{4}{*}{0.772} \\
\hline & & No & 35 & 44.3 & \\
\hline & \multirow[t]{2}{*}{2} & Yes & 28 & 58.3 & \\
\hline & & No & 20 & 41.7 & \\
\hline \multirow{4}{*}{$\begin{array}{l}\text { Have you ever noticed bad } \\
\text { breath? }\end{array}$} & \multirow{2}{*}{1} & Yes & 36 & 45.6 & \multirow{4}{*}{0.629} \\
\hline & & No & 43 & 54.4 & \\
\hline & \multirow{2}{*}{2} & Yes & 24 & 50 & \\
\hline & & No & 24 & 50 & \\
\hline \multirow{8}{*}{$\begin{array}{l}\text { What kind of toothpaste do } \\
\text { you use? (multiple answers } \\
\text { possible) }\end{array}$} & \multirow{4}{*}{1} & Sensitive & 26 & 32.9 & \multirow{8}{*}{0.107} \\
\hline & & Normal & 26 & 32.9 & \\
\hline & & Whitening & 24 & 30.4 & \\
\hline & & Non-fluoride & 3 & 3.8 & \\
\hline & \multirow{4}{*}{2} & Sensitive & 21 & 43.8 & \\
\hline & & Normal & 17 & 35.4 & \\
\hline & & Whitening & 9 & 18.8 & \\
\hline & & Non-fluoride & 1 & 2.1 & \\
\hline \multirow{6}{*}{$\begin{array}{l}\text { Do you seek a routine dental } \\
\text { visit for oral hygiene } \\
\text { maintenance? }\end{array}$} & \multirow{3}{*}{1} & Once in a year & 16 & 20.3 & \multirow{6}{*}{0.064} \\
\hline & & Twice in a year & 24 & 30.4 & \\
\hline & & Only if a problem occurs & 39 & 49.4 & \\
\hline & \multirow{3}{*}{2} & Once in a year & 16 & 33.3 & \\
\hline & & Twice in a year & 17 & 35.4 & \\
\hline & & Only if a problem occurs & 15 & 31.3 & \\
\hline
\end{tabular}

Table 6-2. Mann-Whitney U test results based on class levels

\begin{tabular}{|c|c|c|c|c|c|}
\hline Question & Class & Answers & $\mathbf{n}$ & $\%$ & $\mathbf{p}$ \\
\hline \multirow{9}{*}{$\begin{array}{l}\text { How much time do you take for } \\
\text { cleaning your teeth? }\end{array}$} & \multirow{5}{*}{1} & 1 minute & 16 & 20.3 & \multirow{9}{*}{0.884} \\
\hline & & $1-2$ minute & 33 & 41.8 & \\
\hline & & 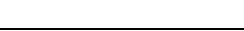 & & & \\
\hline & & More than 2 minutes & 30 & 38.0 & \\
\hline & & Don't know & - & - & \\
\hline & \multirow[t]{4}{*}{2} & 1 minute & 6 & 12.5 & \\
\hline & & $1-2$ minute & 28 & 58.3 & \\
\hline & & More than 2 minutes & 13 & 27.1 & \\
\hline & & Don't know & 1 & 2.1 & \\
\hline \multirow{6}{*}{$\begin{array}{l}\text { How often do you clean your } \\
\text { teeth? }\end{array}$} & \multirow{3}{*}{1} & Once in a day & 10 & 12.7 & \multirow{6}{*}{0.360} \\
\hline & & Twice in a day & 56 & 70.9 & \\
\hline & & More than twice & 13 & 16.5 & \\
\hline & \multirow{3}{*}{2} & Once in a day & 4 & 8.3 & \\
\hline & & Twice in a day & 42 & 87.5 & \\
\hline & & More than twice & 2 & 4.2 & \\
\hline
\end{tabular}


Table 6-3. Mann-Whitney U test results based on class levels

\begin{tabular}{|c|c|c|c|c|c|}
\hline Question & Class & Answers & $\mathbf{n}$ & $\%$ & $\mathbf{p}$ \\
\hline \multirow{20}{*}{$\begin{array}{l}\text { How pleased are you } \\
\text { with the color of your } \\
\text { teeth? (1-10) }\end{array}$} & \multirow{10}{*}{1} & 1 & 5 & 6.3 & \multirow{20}{*}{0.522} \\
\hline & & 2 & 2 & 2.5 & \\
\hline & & 3 & 3 & 3.8 & \\
\hline & & 4 & 4 & 5.1 & \\
\hline & & 5 & 10 & 12.7 & \\
\hline & & 6 & 15 & 19.0 & \\
\hline & & 7 & 12 & 15.2 & \\
\hline & & 8 & 19 & 24.1 & \\
\hline & & 9 & 3 & 3.8 & \\
\hline & & 10 & 6 & 7.6 & \\
\hline & \multirow{10}{*}{2} & 1 & 0 & 0 & \\
\hline & & 2 & 0 & 0 & \\
\hline & & 3 & 1 & 2.1 & \\
\hline & & 4 & 5 & 10.4 & \\
\hline & & 5 & 7 & 14.6 & \\
\hline & & 6 & 6 & 12.5 & \\
\hline & & 7 & 14 & 29.2 & \\
\hline & & 8 & 8 & 16.7 & \\
\hline & & 9 & 3 & 6.3 & \\
\hline & & 10 & 4 & 8.3 & \\
\hline
\end{tabular}

Table 7-1. Mann-Whitney U test results based on gender

\begin{tabular}{|c|c|c|c|c|c|}
\hline Question & Gender & Answers & $\mathbf{n}$ & $\%$ & $\mathbf{p}$ \\
\hline \multirow{4}{*}{$\begin{array}{l}\text { Have you ever noticed } \\
\text { bleeding in your gums? }\end{array}$} & \multirow[b]{2}{*}{ Female } & Yes & 45 & 60 & \multirow{4}{*}{0.368} \\
\hline & & No & 30 & 40 & \\
\hline & \multirow[b]{2}{*}{ Male } & Yes & 27 & 51.9 & \\
\hline & & No & 25 & 48.1 & \\
\hline \multirow{4}{*}{$\begin{array}{l}\text { Have you ever noticed } \\
\text { bad breath? }\end{array}$} & \multirow[t]{2}{*}{ Female } & Yes & 36 & 48 & \multirow{4}{*}{0.838} \\
\hline & & No & 39 & 52 & \\
\hline & \multirow{2}{*}{ Male } & Yes & 24 & 46.2 & \\
\hline & & No & 28 & 53.8 & \\
\hline \multirow{8}{*}{$\begin{array}{l}\text { What kind of toothpaste } \\
\text { do you use? (multiple } \\
\text { answers possible) }\end{array}$} & \multirow{4}{*}{ Female } & Sensitive & 28 & 37.3 & \multirow{8}{*}{$0.008 *$} \\
\hline & & Normal & 20 & 26.7 & \\
\hline & & Whitening & 24 & 32.0 & \\
\hline & & Non-fluoride & 3 & 4.0 & \\
\hline & \multirow{4}{*}{ Male } & Sensitive & 19 & 36.5 & \\
\hline & & Normal & 23 & 44.2 & \\
\hline & & Whitening & 9 & 17.3 & \\
\hline & & Non-fluoride & 1 & 1.9 & \\
\hline \multirow{6}{*}{$\begin{array}{l}\text { Do you seek a routine } \\
\text { dental visit for oral } \\
\text { hygiene maintenance? }\end{array}$} & \multirow{3}{*}{ Female } & Once in a year & 21 & 28.0 & \multirow{6}{*}{$0.001 *$} \\
\hline & & Twice in a year & 27 & 36.0 & \\
\hline & & $\begin{array}{l}\text { Only if a problem } \\
\text { occurs }\end{array}$ & 27 & 36.0 & \\
\hline & \multirow{3}{*}{ Male } & Once in a year & 11 & 21.2 & \\
\hline & & Twice in a year & 14 & 26.9 & \\
\hline & & $\begin{array}{l}\text { Only if a problem } \\
\text { occurs }\end{array}$ & 45 & 60 & \\
\hline
\end{tabular}


Table 7-2. Mann-Whitney U test results based on gender

\begin{tabular}{|c|c|c|c|c|c|}
\hline Question & Gender & Answers & $\mathbf{n}$ & $\%$ & $\mathbf{p}$ \\
\hline \multirow{6}{*}{$\begin{array}{l}\text { How often do you clean your } \\
\text { teeth? }\end{array}$} & \multirow{3}{*}{ Female } & Once in a day & 3 & 4.0 & \multirow{6}{*}{$0.003^{*}$} \\
\hline & & Twice in a day & 63 & 84.0 & \\
\hline & & More than twice & 9 & 12.0 & \\
\hline & \multirow{3}{*}{ Male } & Once in a day & 11 & 21.2 & \\
\hline & & Twice in a day & 35 & 67.3 & \\
\hline & & More than twice & 6 & 11.5 & \\
\hline \multirow{8}{*}{$\begin{array}{l}\text { How much time do you take } \\
\text { for cleaning your teeth? }\end{array}$} & \multirow{4}{*}{ Female } & 1 minute & 9 & 12.0 & \multirow{8}{*}{$0.000 *$} \\
\hline & & $1-2$ minute & 40 & 53.3 & \\
\hline & & More than 2 minutes & 26 & 34.7 & \\
\hline & & Don’t know & - & - & \\
\hline & \multirow{4}{*}{ Male } & 1 minute & 13 & 25.0 & \\
\hline & & $1-2$ minute & 21 & 40.4 & \\
\hline & & More than 2 minutes & 17 & 32.7 & \\
\hline & & Don’t know & 1 & 1.9 & \\
\hline
\end{tabular}

$* \mathrm{p}<0.05$

Table 7-3. Mann-Whitney U test results based on gender

\begin{tabular}{|c|c|c|c|c|c|}
\hline Question & Gender & Answers & $\mathbf{n}$ & $\%$ & $\mathbf{p}$ \\
\hline \multirow{20}{*}{$\begin{array}{l}\text { How pleased are you } \\
\text { with the color of your } \\
\text { teeth? (1-10) }\end{array}$} & \multirow{10}{*}{ Female } & 1 & 3 & 4 & \multirow{20}{*}{$0.000 *$} \\
\hline & & 2 & - & - & \\
\hline & & 3 & 1 & 1.3 & \\
\hline & & 4 & 7 & 9.3 & \\
\hline & & 5 & 12 & 16.0 & \\
\hline & & 6 & 13 & 17.3 & \\
\hline & & 7 & 16 & 21.3 & \\
\hline & & 8 & 12 & 16.0 & \\
\hline & & 9 & 3 & 4.0 & \\
\hline & & 10 & 8 & 10.7 & \\
\hline & \multirow{10}{*}{ Male } & 1 & 2 & 3.8 & \\
\hline & & 2 & 2 & 3.8 & \\
\hline & & 3 & 3 & 5.8 & \\
\hline & & 4 & 2 & 3.8 & \\
\hline & & 5 & 5 & 9.6 & \\
\hline & & 6 & 8 & 15.4 & \\
\hline & & 7 & 10 & 19.2 & \\
\hline & & 8 & 15 & 28.8 & \\
\hline & & 9 & 3 & 5.8 & \\
\hline & & 10 & 2 & 3.8 & \\
\hline
\end{tabular}




\section{DISCUSSION}

This study included questions which were about oral and dental health awareness, knowledge, habits and selfassessment and were modified from several studies $(12,13,14,15)$. One of the strengths of this study was that a mixture of questions was used rather than being bound to a single questionnaire. Some of the questions were taken from the English version of the Hiroshima University - Dental Behavior Inventory (HU-DBI) and adapted to our questionnaire (16), while some were chosen to evaluate the links between each question. The responses to these questions were used for comparison in terms of the participants' genders and class years. Another strength of the study was that it drew attention to oral and dental health awareness among dental students and evaluates oral health awareness from the perspective of a future health practitioner. The fact that the study was conducted only with preclinical students was the limitation of the study.

A reliability coefficient of at least $70 \%$ is indicative of the success of a measurement instrument. It shows that the internal consistency of the instrument is assured, and the conclusions can be relied upon.

When the preclinical students were evaluated in term of their class years, it was observed that the 1st-year and 2nd-year participants provided similar answers. The reason for this outcome was thought as that the sample population consisted of homogenous groups. Even if the knowledge levels of the clinical students were not evaluated, it was found that the preclinical students' general responses were similar between their class year values. There were significant differences between the participant group only in selected questions.

Moheet et al. asked preclinical and clinical dental students to fill out HU-DBI to perform oral health-related assessments and compare their attitudes. A greater majority of the preclinical students concluded that they did not consider visiting the dentist until they had a toothache in comparison to the clinical students, and they noticed more bleeding while brushing their teeth (13). Dagli et al. reported that clinical and preclinical dental students have almost the same awareness of dental health behavior and attitudes based on HU-DBI (17).

Although the students' awareness-related results showed that tooth brushing technique is important, it was determined that the majority did not know about interdental aids, xylitol and the beginning age of toothbrushing. Although they reported that they did not receive training on this subject before in their undergraduate education, it was seen that $52 \%$ of them provided oral and dental health education to others. Dentists were important role models for patients in answers given to questions about oral hygiene procedures. Oral hygiene procedures may be added to the preclinical curriculum of these socially responsible preclinical dental students, even if they are not performing treatments, yet. The responses of the participants of this study to the questions on oral habits and awareness were also found to be consistent. The responses to the habit-related questions and awarenessrelated questions were correlated well with each other.
Those who reported less bleeding were found to have better oral hygiene habits. The vast majority of those who said they knew about fluoride had good oral hygiene. It was observed that the self-assessment and habitual responses were consistent with each other. As the starting age of the use of fluoride toothpaste, the majority gave the answer of 6 years, but according to the AAPD (American Academy of Pediatric Dentistry), it can be used in the age range of 3-6 years and younger than 3 years, while only the amount of use varies according to age group. In this case, the result was interpreted as that the students did not yet have enough knowledge about this issue because they were at the beginning of their education (18).

The finding in this study that the participants provided the response of visiting the dentist two times a year, which was frequent, and they responded as they did not smoke to the question about smoking was interpreted as a high level of oral health awareness.

Y1ldız and Doğan compared oral health attitudes and behaviors between preclinical and clinical dental students using HU-DBI. They determined that the preclinical students were significantly more concerned about their tooth color than the clinical students, they were more dissatisfied with gum health, and they did not visit the dentist until a toothache occurred. The preclinical students stated that they had a significant tendency to have bleeding gums while brushing their teeth compared to the clinical students. It was determined that dental students should participate in a comprehensive program regarding their self-care habits starting from their initial year of education (19). On the other hand, in our study, only preclinical students' oral and dental health behaviors were evaluated, and there was no statistically significant difference between the first- and second-year participants in terms of their responses to the questions.

Halawany et al. evaluated the oral and dental health attitudes and behaviors of preclinical and clinical students, where $61.8 \%$ of participants stated that regular dental follow ups should be carried out every 6 months, and $72.6 \%$ stated that they visited the dentist only when a problem occurred. It was suggested that dental students should be taught the necessary skills in achieving good oral hygiene, and they should be informed about various aspects of oral health (20). In this study, $25.2 \%$ of the students stated that they went to the dentist once a year, $32.3 \%$ of them stated they went twice a year, and $42.5 \%$ of them stated they visited the dentist only if a problem occurred. In both studies the percentage of those who visited the dentist only when there is a problem is higher and the studies are consistent in this respect.

Gupta et al. investigated the oral and dental health attitudes, knowledge and behaviors of dentistry students. It was reported that all students at the clinical stage examined their oral cavity, and most students visited the dentist only when necessary. It was stated that students should be a better model to society in terms of maintaining oral health, they should be motivated to prevent oral diseases and encouraged to have classes on oral and dental health earlier, and more comprehensive dental training should be given to them regarding preventive practices (21). The results of this study were consistent with the idea of the necessity of providing 
dental students with comprehensive dental training in their classes at earlier points in their education.

In the study by Singh et al., undergraduate 2nd- and 3rdyear students were asked to evaluate their oral care. It was reported that the undergraduate dental health students generally had good knowledge and skills in terms of oral health self-care; however, they experienced inconsistencies in their practices of oral care (13). In our study, the 1st- and 2nd-year preclinical students were asked to evaluate their oral and dental health habits. An increased level of awareness was identified among the 2nd-year students. Additionally, some basic issues including the use of remineralization agents like casein phosphopeptide-stabilized amorphous calcium phosphate (Tooth Mousse, GC, Tokyo, Japan) were not known among the preclinical students. This result may be explained by the participants' education schedule, the fact that they were just starting their training at the school of dentistry, and the possibility that they had not had any training on oral hygiene and dental health before their dentistry education. Moreover, this outcome was compatible with the result reported in the study by Singh et al., where there was no group difference between the preclinical students in terms of their knowledge levels (13).

The dental satisfaction levels of 1st- and 2nd-year Malaysian dental students with their oral hygiene practices were evaluated, and the dental satisfaction levels of the participants were found to be positive. It was stated that teaching oral and dental health attitudes and behaviors to dental students may increase their dental satisfaction levels (22). In our study, two questions were asked for to evaluate these levels of the participants regarding their oral hygiene. These questions were: "How would you describe your present state of dental health?" and "How pleased are you with the color of your teeth?" The dental satisfaction level of our study's participants were found similar to those reported in the study by Priya et al.

Peker et al. applied the Turkish version of the HU-DBI among preclinical and clinical dental students in Istanbul. They determined that the change in the oral health attitudes and behaviors of the participants reflected their educational experience. In the same study, the dental health awareness and behavior levels of the clinical students were found to be higher than those of the preclinical students. The authors also reported that comprehensive programs aiming to improve behaviors and knowledge should be implemented from the beginning of dentistry education (23). Even if this parameter was not evaluated with the clinical students in our study, our research also aimed to improve dental awareness at early stages of dentistry education, and this point was compatible with the study conducted by Peker et al.

Peker and Alkurt, who evaluating the dental behaviors and attitudes of preclinical and clinical dental students, stated that knowledge and awareness about oral and dental health increased as education level increased, in accordance with study of Dumitrescu et.al (24,25). Furthermore, they found the oral and dental healthcare knowledge and awareness levels in the female participants to be better than those in the male participants (24). These results were consistent with the results obtained in our study.

\section{CONCLUSION}

Dental students may influence the attitudes of the community in which they live. Dental students' oral health knowledge and habits have a potential effect on improving the oral health of individual patients and the community. Preclinical students should look after their oral care. This awareness must be achieved in the first and second years of their preclinical training.

The knowledge and attitudes of dentistry students on oral and dental hygiene and health should be measured by reapplying the questionnaire that was used in this study in future studies with different populations and variables.

Dental students should always have a sufficient oral health routine. Their overall oral hygiene and maintenance and their interest in this topic may only have a positive effect on their patients and the community. These reasons shed light on the importance of oral healthcare education, which should be included in the 1st and 2 nd years of the preclinical training of dental students.

Authors's Contributions: Idea/Concept: A.T.G.; Design: M.M.E.; Data Collection and/or Processing: A.T.G., G.Ç; Analysis and/or Interpretation: A.T.G., M.M.E., G.Ç; Literature Review: A.T.G., M.M.E.; Writing the Article: A.T.G., M.M.E.; Critical Review: A.T.G.

\section{REFERENCES}

1. Özkan Karaca E, Tunar OL. Yeditepe Üniversitesi Diş Hekimliği Fakültesi öğrencilerinin ağız sağlığ1 tutum ve davranışlarının değerlendirilmesi. Yeditepe J Dent. 2020; 16(1): 54-8.

2. Gürsoy H, Dölekoğlu S, Özçakır-Tomruk C, ÖzkurtKayahan Z. Yeditepe Üniversitesi Diş Hekimliği Fakültesi öğrencilerinde ağız-diş sağlığı tutum ve davranışlarının değerlendirilmesi. Atatürk Üniv Diş Hek Fak. Derg. 2016; 26(1): 1-7.

3. McGlone P, Watt R, Sheiham A. Evidence-based dentistry: an overview of the challenges in changing professional practice. Br Dent J. 2001; 190(12): 6369.

4. Brown G, Manogue M, Rohlin M. Assessing attitudes in dental education: is it worthwhile? Br Dent J. 2002; 193(12): 703-7.

5. Autio-Gold J, Tomar SL. Dental students' opinions and knowledge about caries management and prevention. J Dent Educ. 2007; 72(1): 26-32.

6. Khami MR, Virtanen JI, Jafarian M, Murtomaa H. Prevention-oriented practice of Iranian senior dental students. Eur J Dent Educ. 2007; 11(1): 48-55.

7. Barrieshi-Nusair K, Alomari Q, Said K. Dental health attitudes and behavior among dental students in Jordan. Community Dent Health. 2006; 23(3): 14751.

8. Vangipuram S, Rekha R, Radha G, Pallavi SK. Assessment of oral health attitudes and behavior among undergraduate dental students using Hiroshima University Dental Behavioral Inventory HU-DBI. Journal of Indian Assoc Public Health Dent. 2015; 13(1): 52-7. 
9. Nilchian F, Kazemi SH, Abbasi M, Ghoreishian F, Kowkabi M. Evaluation of Isfahan's dental students' awareness about preventive dentistry. J Dent Shiraz Univ Med Sci. 2014; 15(1): 1-5.

10. Ahamed S, Moyin S, Punathil S, Patil NA, Kale VT, Pawar G. Evaluation of the oral health knowledge, attitude and behavior of the preclinical and clinical dental students. J Int Oral Health. 2015; 7(6): 65-70.

11. Yao K, Yao Y, Shen X, Lu C, Guo Q. Assessment of the oral health behavior, knowledge and status among dental and medical undergraduate students: a crosssectional study. BMC Oral Health. 2019;19(1): 26.

12. Daya D, Teja U, Paturu DB, Bhumanapalli R, Sreenivas N, Vijay C, et al. Evaluation of oralhygiene awareness and practice among dental students. J Dr. NTR Univ Health Sci. 2017; 6(1): 248.

13. Kirchhoff J, Filippi A. Comparison of oral health behavior among dental students, students of other disciplines, and fashion models in Switzerland. Swiss Dent J SSO. 2015; 125(12): 1337-44.

14. Singh S, Pottapinjara S. Dental undergraduate students' knowledge, attitudes and practices in oral health self-care: A survey from a South African university. Afr J Health Professions Educ. 2017; 9(2): 83-7.

15. Özalp N, Dağ C, Ökte Z. Oral health knowledge among dental students. Clin Dent Res. 2012; 36(1): 18-24.

16. Moheet IA, Farooq I. Self-reported differences between oral health attitudes of pre-clinical and clinical students at a dental teaching institute in Saudi Arabia. Saudi Dent J. 2013; 25(4): 149-52.

17. Dagli RJ, Tadakamadla S, Dhanni C, Duraiswamy P, Kulkarni S. Self reported dental health attitude and behavior of dental students in India. J Oral Sci. 2008; 50(3): 267-72.

18. American Academy of Pediatric Dentistry. Fluoride therapy. The reference manual of pediatric dentistry. Chicago, Ill.: American Academy of Pediatric Dentistry. 2020; 288-91.

19. Yıldız S, Doğan B. Self reported dental health attitudes and behaviour of dental students in Turkey. Eur J Dent. 2011; 5(3): 253-9.

20. Halawany HS, Abraham NB, Jacob V, Al-Maflehi N. The perceived concepts of oral health attitudes and behaviors of dental students from four Asian countries. Saudi J Dent Res. 2015; 6(2): 79-85.

21. Gupta S, Saxena S, Sikka N, Bhatia G. Oral health attitude, knowledge, and behavior of dental students of Jaipur, Rajasthan: A comparative study. J Indian Assoc Public Health Dent. 2015; 13(4): 459-464.

22. Priya H, Chauhan A, Kumar M. Factors affecting dental satisfaction among Malaysian dental students. Int J Dent Clinics. 2011; 3(2): 5-8.

23. Peker K, Uysal Ö, Bermek G. Dental training and changes in oral health attitudes and behaviors in Istanbul dental students. J Dent Edu. 2010; 74(9): 1017-23.

24. Peker I, Alkurt MT. Oral health attitudes and behavior among a group of Turkish dental students. Eur J Dent. 2009; 3(1): 24-31.
25. Dumitrescu AL, Kawamura M, Sasahara H. An assessment of oral self-care among Romanian dental students using the Hiroshima University - Dental Behavioural Inventory. Oral Health Prev Dent. 2007; 5(2): 95-100. 